\title{
Third-generation internet-based brief interventions for problem drinkers: how far can technology take us, and what types of drinkers can be reached?
}

Trevor van Mierlo

From International Network on Brief Interventions for Alcohol Problems (INEBRIA) Meeting 2011

Boston, MA, USA. 21-23 September 2011

For over a decade, a number of randomized controlled trials (RCTs) have found that internet-based brief intervention (IBBI) can reduce consumption in people with alcohol use disorders. As technology becomes increasingly sophisticated, IBBI has the potential to offer highly tailored feedback to different populations. First launched in 2005, CheckYourDrinking.net (CYD), version 3.0, is a free anonymous IBBI that has undergone several randomized controlled trials and technical upgrades. Apart from the free online version, the technology has been modified for several specific populations such as college students, youth aged 13-17, public health institutions, and for use as a screening tool in private clinics. To illustrate how algorithms can be modified, we are examining data from 21,640 Canadian men (59\%) and women (41\%) who anonymously accessed CheckYourDrinking.net version 2.0 from April 8, 2008, to July 28, 2010. Through describing CYD's development methodology and research-based maturation process, we illustrate how IBBI can be tailored for special populations. Technical limitations and other barriers are discussed. The purpose of this presentation is to share knowledge of the resources required for the ongoing technical enhancement and maintenance of IBBIs. With the use of sophisticated algorithms, IBBIs hold the exciting potential of providing highly tailored feedback to not only people with problem drinking but for those with specific unhealthy drinking patterns (i.e., heavy episodic drinking) and for special populations across languages and cultures.

Rotman School of Management, University of Toronto, Toronto, Ontario, Canada

C 2012 van Mierlo; licensee BioMed Central Ltd. This is an Open Access article distributed under the terms of the Creative Commons Attribution License (http://creativecommons.org/licenses/by/2.0), which permits unrestricted use, distribution, and reproduction in any medium, provided the original work is properly cited.
In order to fully understand the potential of IBBI technology, further research is required.

Published: 9 October 2012

doi:10.1186/1940-0640-7-S1-A90

Cite this article as: van Mierlo: Third-generation internet-based brief interventions for problem drinkers: how far can technology take us, and what types of drinkers can be reached? Addiction Science \& Clinical Practice 2012 7(Suppl 1):A90.

Submit your next manuscript to BioMed Central and take full advantage of:

- Convenient online submission

- Thorough peer review

- No space constraints or color figure charges

- Immediate publication on acceptance

- Inclusion in PubMed, CAS, Scopus and Google Scholar

- Research which is freely available for redistribution Submit your manuscript at
www.biomedcentral.com/submit C Biomed Central
C Biomed Central 